\title{
スラミングに対するクロスデッキパネルの 弾性応答について
}

\section{正 員 遠 山 泰 美*}

Hydroelastic Responses of Cross Deck Panel to Slamming

by Yasumi Toyama, Member

\begin{abstract}
Summary
The objective of this study is to reveal the hydroelastic behavior of the cross deck structure of a high speed catamaran subjected to slamming load. An analytical method using flat plate approximation is proposed to solve the slamming problem of the two dimensional structures where the hydroelastic effects as well as the pile up water on the free surface are accounted for.

Dynamic responses of simply supported seven-span panels penetrating the wave crest are analyzed. It is found that the maximum deflection and bending moment at the location of initial hit tend to be proportional to the impact velocity as far as the wave profile is relatively flat and the impact velocity is high enough. The results are similar to those obtained by Faltinsen et al. A simple equation to estimate the maximum deflection of the panel is obtained by considering the transformation of fluid kinetic energy into the strain energy.
\end{abstract}

\section{1. 緒言}

高速双胴船は比較的荒い海象のもとで，双胴間のクロス デッキ下面に波浪衝撃を受けることがある。安全性の評価 は衝撃圧力の大きさだけでなく, 構造に発生する変形や応 力の応答に注目して行う必要があり, 構造と流体との相互 作用問題を解明することが重要である。波浪衝撃における 弾性の影響についての最近の研究(1) のうち, Faltinsen ら はクロスデッキの衝撃問題を取り上げ, 応力応答は落下速 度の 2 乗ではなく 1 乗に比例するという新しい重要な見 解4), を) 模型実験及び計算によって示している。しかし, な ぜ速度に比例するのかについては, あまり議論されていな いようであり，本論文の1つの目的はこれを明らかにする ことにある。

筆者はWagner の衝撃理論8) を2 次元任意形状物体の 衝撃問題9) や 3 次元問題 ${ }^{10)}$ に抎張することを試みて来た。 ここでは平板近似を用い, 弾性変形を伴う 2 次元衝撃問題

\section{* 三井造船(株)}

原稿受理 平成 10 年 1 月 7 日 春季講演会において講演 平成 10 年 5 月 14,15 日
に適用できる解析的手法の提案を行った。計算法の構築に あたり, Wagner と同様の仮定, すなわち浅吃水, 空気の巻 き込みの無視, 重力無視, 非圧縮性流体の仮定を置いた。

\section{2. 弾性変形を考慮した 2 次元水面衝撃理論}

\section{1 自由表面上で上下に運動する 2 次元弾性平板まわ} りの流れ

Fig. 1 亿示すように半径 $a$ の円柱を考え，円柱表面が外 向き速度

$$
V(\theta)=2 \sum_{n=1,2} A_{n} \sin n \theta
$$

でもって運動しているものとする。これに対応する速度ポ

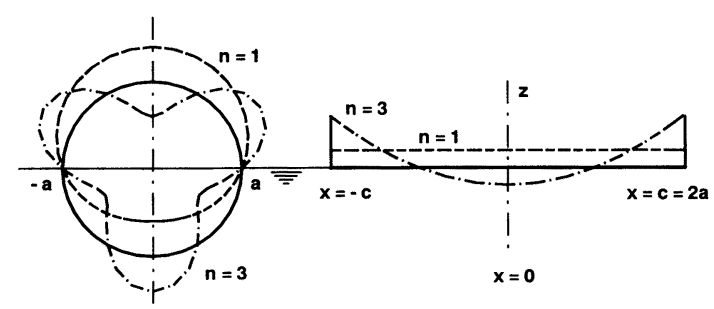

Fig. 1 Transformation of a cylinder into a plate having distributed vertical velocity 
テンシャルは

$$
\phi(r, \theta)=-2 \sum_{n=1,2,} A_{n} a^{n+1} n^{-1} r^{-n} \sin n \theta
$$

で与えられる。等角写像により, 円柱を半幅 $c=2 a$ の平板 に変換し, 平板表面の下向き速度 $v(x)$ を求めると

$v(x) \sin \theta=\sum_{n=1,2,} A_{n} \sin n \theta$, ただし $x=c \cos \theta(3)$

となる。逆に $v(x)$ が与えられていると (3) 式の左辺を Fourier Sine 級数展開することによって, 係数 $A_{n}$ を定め ることができる。 $A_{n}$ が定まると $(2)$ 式を利用して, 流速や 圧力を算定することができる。しかし時間ステップ毎に境 界值問題を解くのは効率的でない。そこで平板表面上の下 向き速度を有限個の三角形状の速度分布の重ね合わせで表 現することを考える。すなわち速度分布を折れ線で近似す ることを考える。Fig. 2 に左右対称問題で接水半幅 $c$ を 2 分割した場合 $(N=2)$ の例を示す。三角形の頂点での速度 をそれぞれ $v_{k}(k=0,1, \cdots, N)$ と表す。平板表面での速度ポ テンシャルの值は (4)式で表される。

$$
\phi(x)=\sum_{k=0}^{N} \phi_{k}=-c \sum_{k=0}^{N} v_{k} \cdot \varphi_{k}(\xi), \xi=x / c
$$

$N=10$ の場合の $\varphi_{k}(\xi)$ の分布を Fig. 3 に示す。 $k$ につい て合計したものは平板の剛体的上下動に対応するものであ り，棈円形状の分布となる。平板の外側の自由表面の上向 き速度はFig. 4 のように表される。

\section{2 自由表面の盛上がり}

自由表面の盛上がりは自由表面での上向き流速を時間で 積分することによって求められる。 $k=0,1, \cdots, N$ に対応す

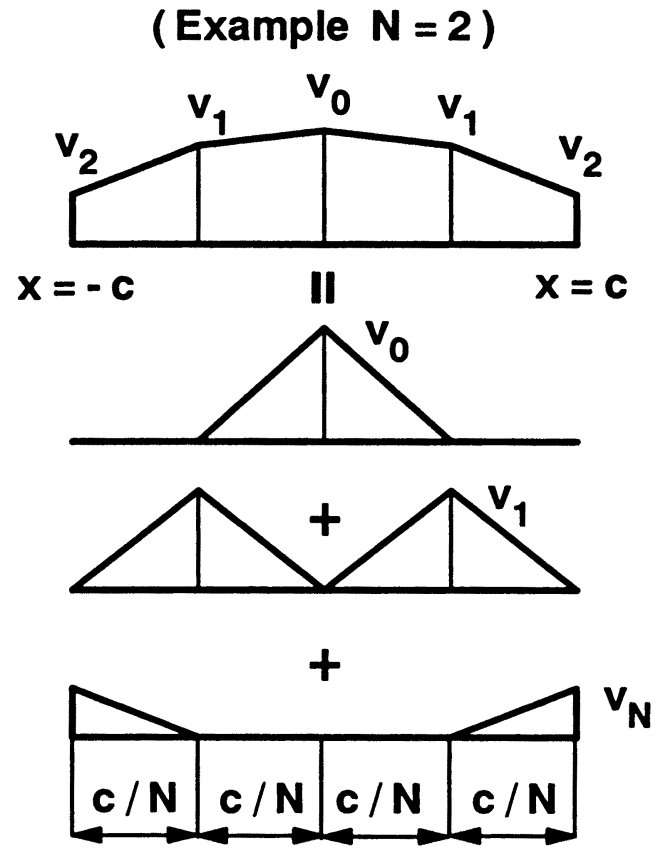

Fig. 2 Decomposition of symmetric velocity into the discrete basic functions
るそれぞれのポテンシャル流れに対し，無次元化された形 で計算しておく。時刻 $t_{1}$ から時刻 $t_{2}=t_{1}+\Delta t$ に変化する間 に接水端位置が $c_{1}$ から $c_{2}$ に移動したとする。このとき $x$ $=c_{2}$ における自由表面の.上昇量の增分を

$$
\Delta \eta\left(c_{1}, c_{2}\right)=\int_{t_{1}}^{t_{2}} v_{k}(t) \cdot f\left(\frac{c_{2}}{c}\right) d t
$$

で表す。ここに $f(\xi)$ は Fig. 4 に示した自由表面の無次元 化上向き流速である。 $v_{k}(t)$ 及び接水幅拡大速度 $d c / d t$ は時 間に対し緩やかに変化するので微小な時間差 $\Delta t$ に対して は(5)式は近似的に

$$
\Delta \eta\left(c_{1}, c_{2}\right) \cong \frac{\bar{v}_{k}}{\dot{c}} \int_{c_{1}}^{c_{2}} f\left(\frac{c_{2}}{c}\right) d c=\frac{c_{2} \bar{v}_{k}}{\dot{c}} \int_{1}^{c_{2} / c_{1}} \frac{f(\xi)}{\xi^{2}} d \xi
$$

$$
\begin{aligned}
& \text { ここに } \\
& \bar{v}_{k}=\left[v_{k}\left(t_{1}\right)+v_{k}\left(t_{2}\right)\right] / 2 \\
& \dot{c}=\left(c_{2}-c_{1}\right) /\left(t_{2}-t_{1}\right)
\end{aligned}
$$

で算出できる。接水端から離れた任意の位置 $x$ での自由表

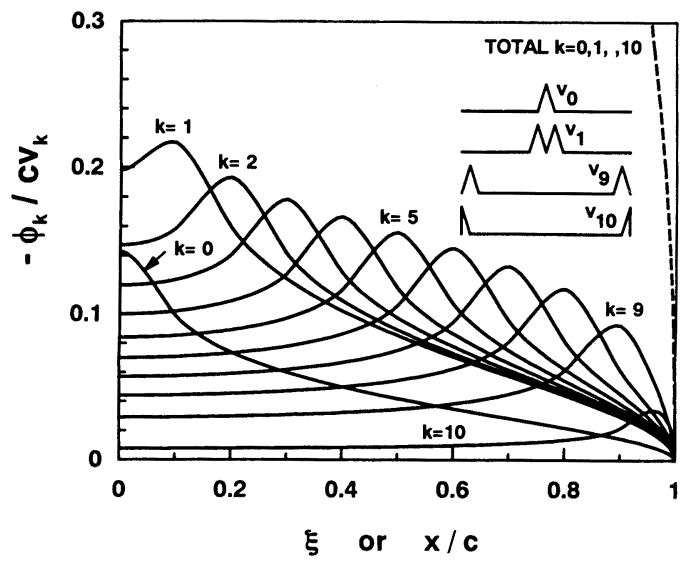

Fig. 3 Velocity potential on the surface of a plate

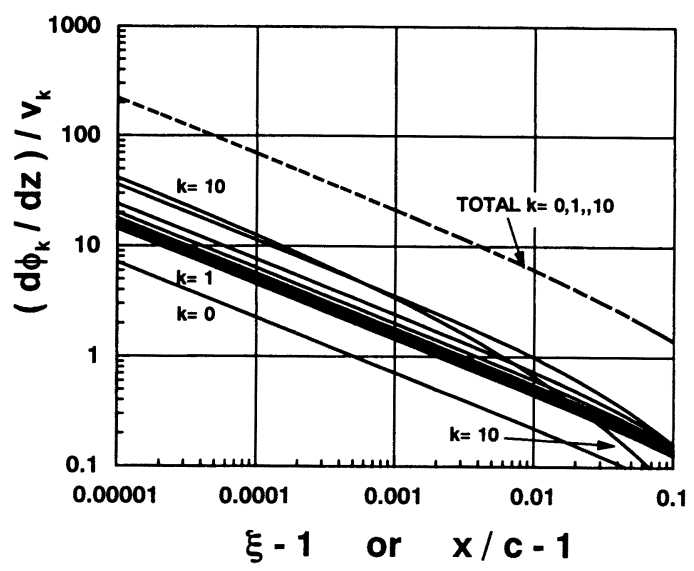

Fig. 4 Vertical velocity on the free surface of the water outside the plate 
面の上昇量増分 $\Delta \eta$ は $(6)$ 式を用い,

$$
\Delta \eta=\Delta \eta\left(c_{1}, x\right)-\Delta \eta\left(c_{2}, x\right)
$$

により求められる。（6) 式の積分項は予め計算しておくこ とができ，Fig. 5 のように表される。

\section{3 衝撃圧力算定式}

(4) 式を Bernoulli $の$ 式

$$
\frac{p}{\rho}=-\frac{\partial \phi}{\partial t}-\frac{1}{2}\left(\frac{\partial \phi}{\partial x}\right)^{2}, \quad \rho: \text { 流体の密度 }
$$

に代入すると衝撃压力算定式

$$
\begin{aligned}
& p=p_{\text {add }}+p_{i m p} \\
& p_{\text {add }} / \rho=c \sum_{k=0}^{N} \dot{v}_{k} \varphi_{k} \\
& \frac{p_{i m p}}{\rho}=\dot{c} \sum_{k=0}^{N} v_{k}\left(\varphi_{k}-\xi \frac{\partial \varphi_{k}}{\partial \xi}\right)-\frac{1}{2}\left(\sum_{k=0}^{N} v_{k} \frac{\partial \varphi_{k}}{\partial \xi}\right)^{2}
\end{aligned}
$$

を得る。(10)式は付加水質量力の項であり, 衝撃現象だけ に特有ではないことから, 狭義の衝撃圧力 (11) 式とは分離 して扱う。接水端で水平流速が無限大になることから，(11） 式の第 2 項により, 衝撃圧力が負となる領域が接水端のご く近傍に限り発生する。この場合, 本モデルでは(11)式の 負圧は零と置き換えて応答解析に利用する。

\section{4 平板と流体との連成運動方程式}

構造は有限要素法 (FEM) によりモデル化を行い, 非接 水状態での固有值解析を行っておく。構造の上向き変位べ クトル $\{w\}$ をドライ固有モード $[\Phi]$ の線型重ねあわせ,

$$
\{w\}=[\Phi]\{q\}, \quad\{q\} \text { : 一般化変位ベクトル }
$$

として表現すると, 構造と流体との運動方程式は,

$$
\begin{aligned}
& \left(\left[M^{*}\right]+\left[M_{a}^{*}\right]\right)\{\ddot{q}\}+\left[C^{*}\right]\{\dot{q}\}+\left[K^{*}\right]\{q\}=\left\{f^{*}\right\} \\
& {\left[M_{a}^{*}\right]=\left[\Phi^{\prime}\right]^{T}\left[M_{a}\right]\left[\Phi^{\prime}\right]=\rho c^{2}\left[\Phi^{\prime}\right]^{T}\left[\bar{M}_{a}\right]\left[\Phi^{\prime}\right]}
\end{aligned}
$$

と表される。ただし $\left[M^{*}\right],\left[M_{a}^{*}\right],\left[C^{*}\right],\left[K^{*}\right],\left\{f^{*}\right\}$ はそれぞ れ一般化構造質量, 付加水質量, 減衰, 剛性, 外力であり, $\left[\Phi^{\prime}\right]$ は接水半幅 $c$ を $N$ 等分した点でのドライモードであ る。無次元化付加水質量マトリックス $\left[\bar{M}_{a}\right]$ は予め $(4)$ 式 の $\varphi_{k}(\xi)$ を用いて計算しておくことができる。例えば $N=$

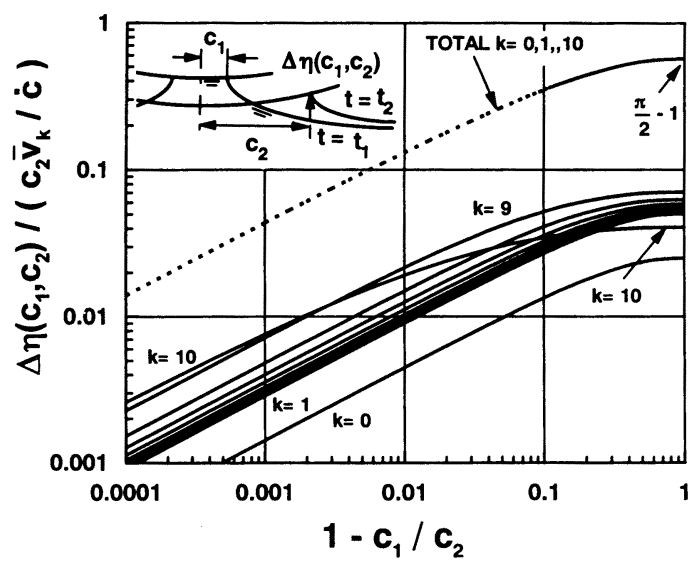

Fig. 5 Increment of free surface elevation at $x=c_{2}$ due to the change of wetted length $c_{1}$ to $c_{2}$
2 (Fig. 2 参照) の場合,

$$
\left[M_{a}\right]=\rho c^{2}\left[\bar{M}_{a}\right]=\rho c^{2}\left[\begin{array}{lll}
0.2008 & 0.2397 & 0.0488 \\
0.2397 & 0.4611 & 0.1289 \\
0.0488 & 0.1289 & 0.0741
\end{array}\right]
$$

となる。(13)式の一般化外力の計算には付加水質量力は含 まれておらず，(11)式を使って算定する。運動方程式(13) 式は Runge-Kutta 法によって時間領域で解く。接水半幅 $c$ は (6)式を利用して接水端での構造表面と自由表面の $z$ 座標が一致するように決定する。

\section{3. 円筒殻の水面落下衝撃応答}

本論文の計算手法の有用性を確認するため，既に発表さ れている実験結果との比較を行った。水面衝撃を受ける円

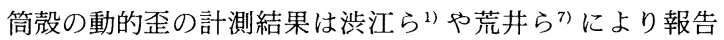
されている。荒井らは差分法に基づく計算との比較を行い 良好な結果を得ている。ここでは渋江らの鋼製円筒壳（外 径 $312 \mathrm{~mm}$, 厚さ $5.1 \mathrm{~mm}$ ) の落下高さ $1 \mathrm{~m}$ に対する実験と の比較を行う。Fig. 6 に下から $0^{\circ}, 10^{\circ}, 20^{\circ}$ 位置での歪の時 系列応答について計算值と計測值との比較を示す。計算で は 6 個の固有モードを考慮し,各モードの減衰比を 0.05 と した。接水半幅の分割数は $N=10$ とした。弾性変形モード の他，剛体モードを取り入れており，衝撃力による減速効 果が考慮されている。歪の最大応答值は計算の方が若干大
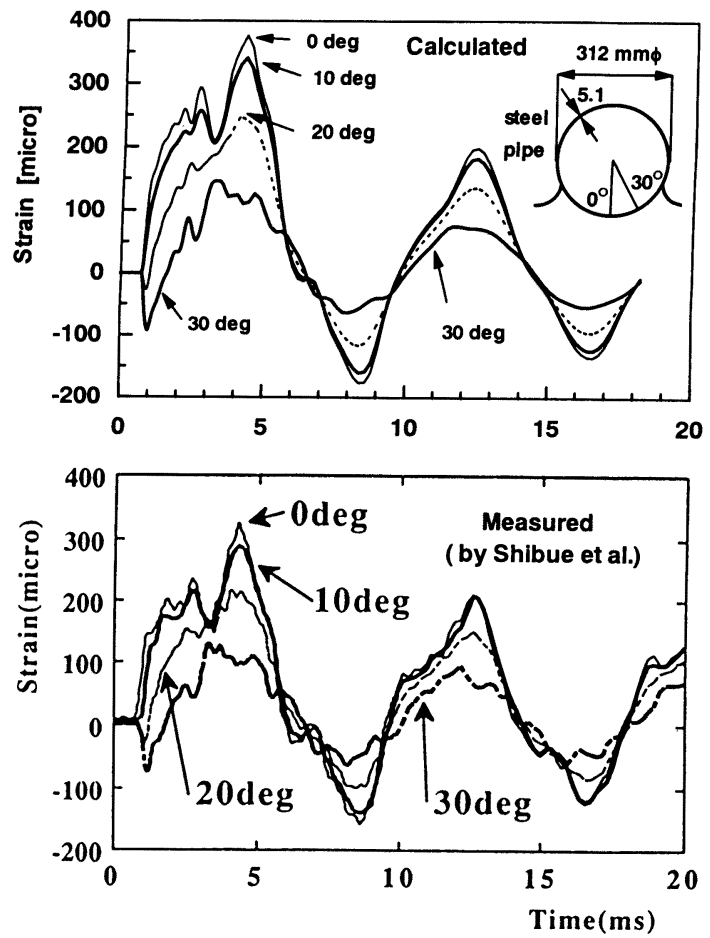

Fig. 6 Comparison between calculated and measured time histories of strains on the cylindrical pipe penetrating flat water surface 
きくなっているが，時間に対する変動の様子は実測値と良 好に対応している。本手法が実用的な精度を有しているこ とが分かる。

\section{4. クロスデッキの動的衝撃応答}

\section{1 計算モデル}

Fig. 7 に計算モデルを示す。クロスデッキはスチフナー 位置で単純支持された等間隔 7 スパンパネルとしてモデル 化する。水面形状は放物線で表し, 原点での曲率半径を $R$ とする。クロスデッキは一定速度 $V$ で水面に対し落下する ものとし，衝撃力による減速を考慮しない。計算に用いた 諸定数を Table 1 に示す。

\section{2 計算結果}

水面の曲率半径とパネルのスパンの比 $R / L$ を $1,2 ， 5$, 10 と変化させ, 落下速度 $V$ を $0.25 \mathrm{~m} / \mathrm{sec}$ から $4 \mathrm{~m} / \mathrm{sec}$ ま で変えてシミュレーションを行った。パネルの撓み $w$, 曲 げモーメント $M$, 接水半幅 $c$, 接水部の相対速度 $v$, パネル に作用する流体力 $F$ の時系列の 1 例を Fig. $8(R / L=5, V$ $=4 \mathrm{~m} / \mathrm{sec}$ ) に示す。各時刻におけるパネルと自由表面の変 形，および衝撃圧力分布を Fig. 9 に示す。スパン中央の相 対速度 $v(0)$ は衝突の瞬間は $V$ であるが，パネルの弾性変 形のために低下し，最大撓みの発生時には再び $V$ まで回 復，その後パネルのスプリングバックにより増加する。衝 撃压力 (11) 式を接水幅にわたり積分した衝撃力 $F_{\text {imp }}$ は, 衝

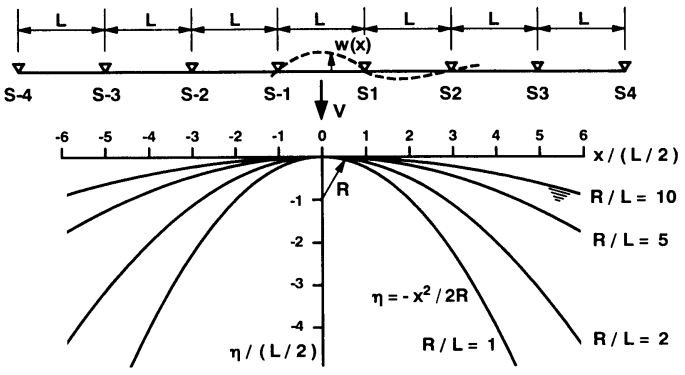

Fig. 7 Simply supported seven-span continuous panel penetrating parabolic wave crest

Table 1 Parameters for the cross deck modeling

\begin{tabular}{|l|l|}
\hline stiffener space (span) & $\mathrm{L}=400 \mathrm{~mm}$ \\
\hline panel thickness & $\mathrm{h}=6 \mathrm{~mm}$ \\
\hline Young's modulus & $\mathrm{E}=71000 \mathrm{MPa}$ \\
\hline Poisson's ratio & $\nu=0.34$ \\
\hline panel density & $\rho_{s}=2.7 \mathrm{ton} / \mathrm{m}^{3}$ \\
\hline fluid density & $\rho=1.025 \mathrm{ton} / \mathrm{m}^{3}$ \\
\hline number of natural modes & $5(1 \mathrm{st}$ to $5 \mathrm{th})$ \\
\hline modal damping ratio & $5=c / c_{0}=0.02$ \\
\hline
\end{tabular}

突の瞬間は

$$
F_{i m p}=2 \pi \rho R V^{2}
$$

となるが，その後の相対速度の低下のために急速に小さく なる。しかし最大撓み発生時を過ぎると逆に相対速度が増 加し, 剛体パネルを仮定した場合より大きな衝撃力となる。 Fig. 8 で無次元化時刻 $t V / L=0.03$ 付近で $F_{i m p}$ が極大とな つているが, これは接水端部のパネルの撓みにより, 水面
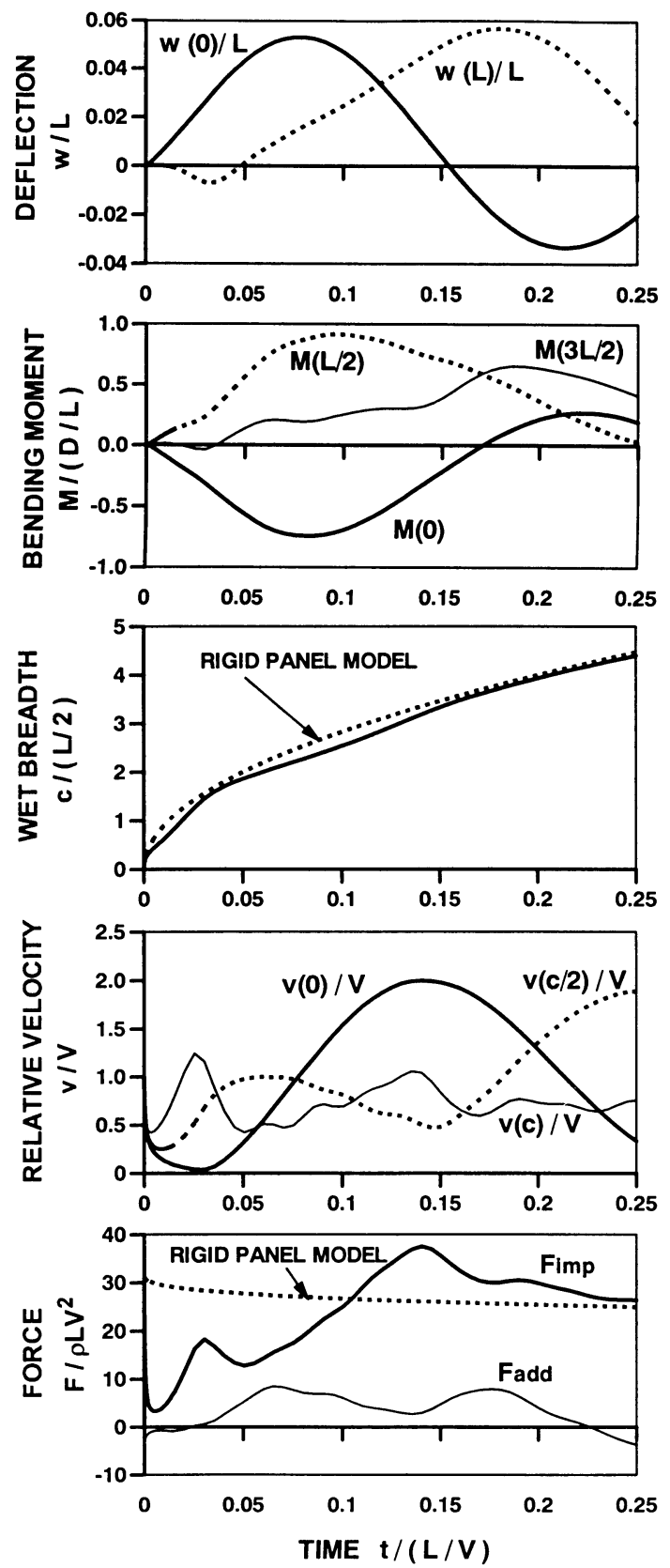

Fig. 8 Time histories of structural responses of sevenspan panels to slamming $(R / L=5, V=4 \mathrm{~m} / \mathrm{sec})$ 

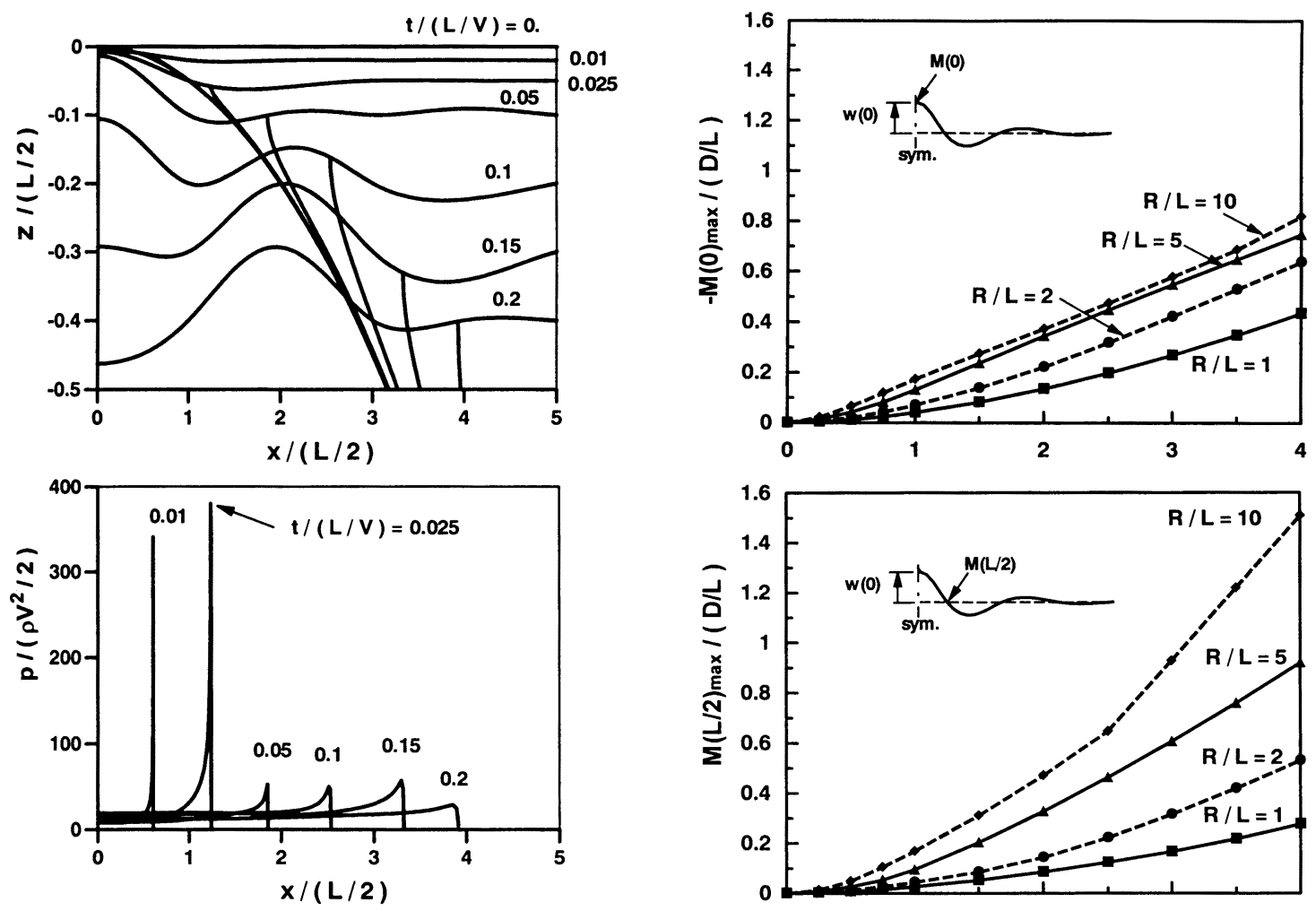

Fig. 9 Elastic deformation, free surface profile and impact pressure distribution $(R / L=5, V=4 \mathrm{~m} / \mathrm{sec})$

との接水角が小さくなり接水長さの挔大速度が大きくなっ ているためである。スパン中央最大撓みと落下速度 $V$ の関 係を Fig. 10 に示す。スパン中央曲げモーメント（hog）及 び支持部曲げモーメント（sag）の最大値と落下速度の関係 をFig. 11 に示す。スパン中央部の最大撓みと曲げモーメ

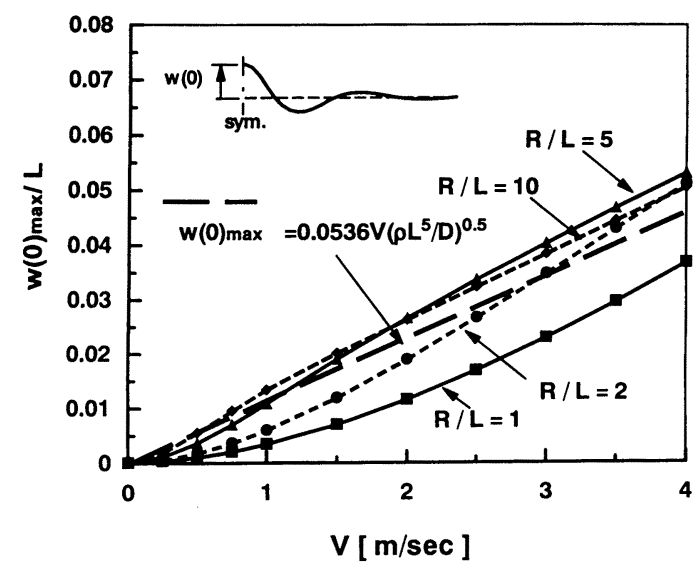

Fig. 10 Relation between maximum central deflection and impact velocity

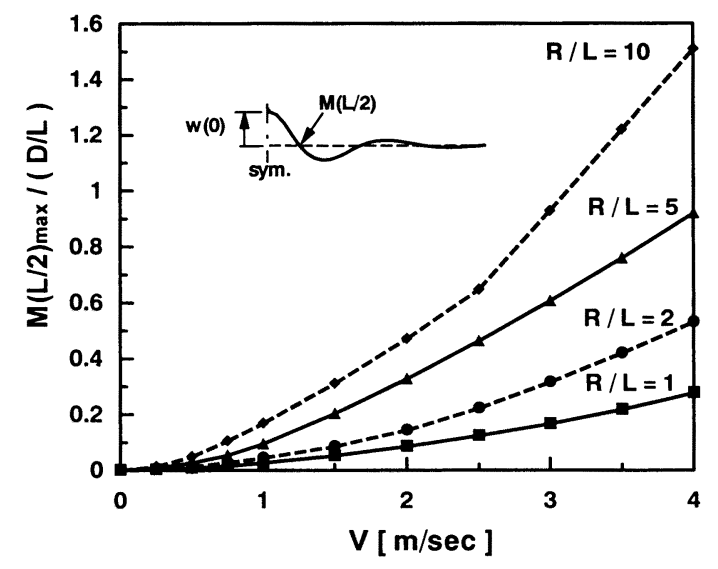

Fig. 11 Relation between maximum bending moment and impact velocity

ントは $R / L=5,10$ の場合, 落下速度に比例する傾向を示 し, 比例定数は $R / L$ にあまり依存していない。一方，支持 部の最大サグモーメントは必ずしも落下速度には比例しな いようである。

\section{3 計算結果に対する考察}

パネルが準静的に応答すると仮定すると，水面との衝突 の瞬間にスパン中央に (16) 式で表される集中荷重が作用す ることになり，静的なスパン中央撓みを計算すると，Fig. 12 の破線のように表される。すなわち落下速度が大きくな るにつれ, 動的影響が大きく現れると考えられる。一般に 荷重の作用時間が固有周期に比べ充分小さい時には動的応 答倍率は 1 より小さくなり，作用時間に比例することが知 られている。衝撃圧力ピークは接水端部にあり, 落下速度 に比例して高速で移動するので, ピーク圧力が中央スパン を通過する時間は落下速度に反比例する。また衝撃力は (16) 式で示すように落下速度の 2 乗に比例するので, 動的 応答倍率を静的応答に掛けると落下速度に比例するという 定性的説明が可能となる。また水面の曲率半径を大きくす ると(16)式により衝撃力は比例的に大きくなるが，ピーク 圧力が中央スパンを通過する時間は曲率半径に反比例する 


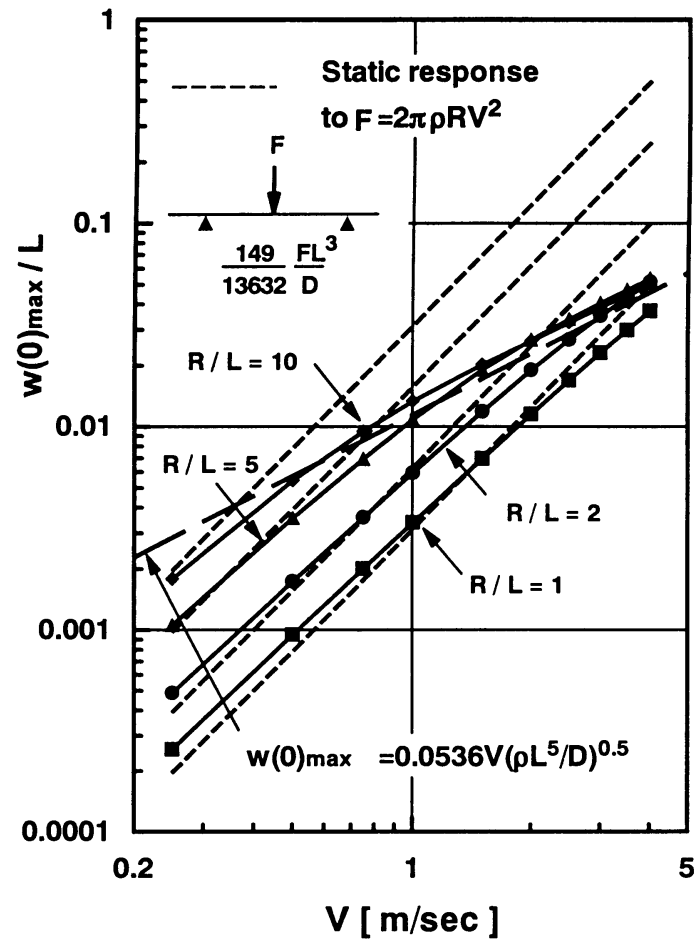

Fig. 12 Comparison of maximum central deflection with quasi static response to a concentrated load at the panel center

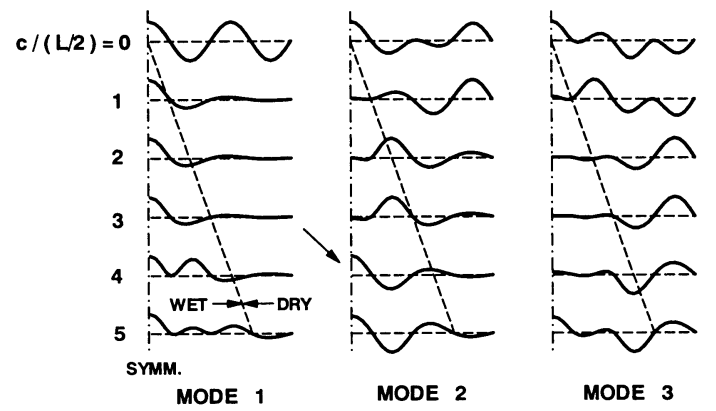

Fig. 13 Natural vibration modes of one--side wetted seven-span panels

ため, 動的応答は曲率半径にあまり依存しないという説明 ができる。

別な解釈はエネルギーの観点からなされる。接水半幅 $C$ を変化させてパネルの固有振動解析を行うと, 固有振動モ ードはFig. 13 のように表され, 接水固有振動数 $f_{w}$ は Fig. 14 のように変化する。1 次固有振動数は $1<2 c / L<3$ の範 囲ではあまり変化しないことが Fig. 14 から分かる。1 次固 有モードについて，撓み $w(0)$ で正規化し一般化付加水質 量と一般化剛性を計算してみると, $1<2 c / L<3$ の範囲では

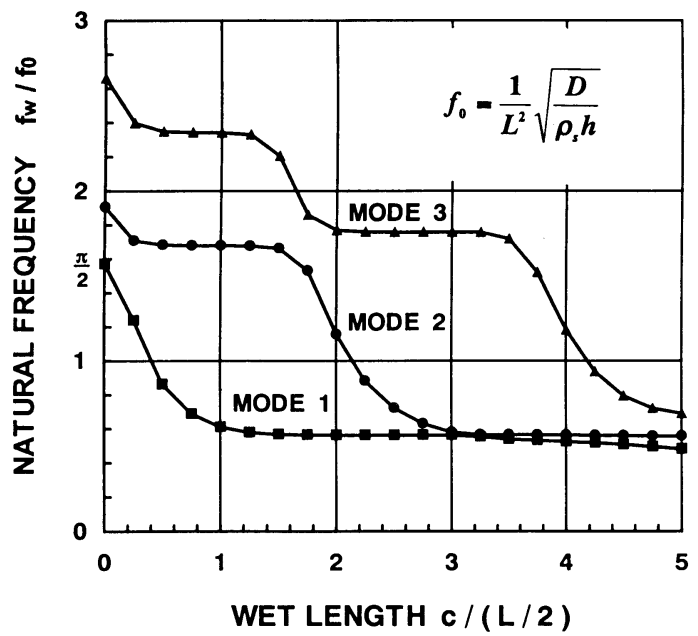

Fig. 14 Natural frequencies of one-side wetted sevenspan panels

$$
\begin{aligned}
& \text { 近似的に一定值 } \\
& \quad M_{w}^{*}=0.27 \rho L^{2} \\
& K_{w}^{*}=94 D / L^{3}, D=E h^{3} / 12\left(1-v^{2}\right)
\end{aligned}
$$

で与えられることが分かる。スパン中央の撓みが最大值を 取るときには付加水質量の持っていた運動エネルギーが全 てパネルの歪エネルギーに変換されたときであるとする と,

$$
M_{w}^{*} V^{2} / 2=K_{w}^{*} w(0)_{\max }^{2} / 2
$$

より

$$
w(0)_{\max }=0.0536 V \sqrt{\rho L^{5} / D}
$$

となり, スパン中央の最大撓みは落下速度に比例するとい う式を得る。(20) 式を Fig. 10, Fig. 12 に記入したところ水 面の曲率半径の大きい場合のシミュレーション結果と比較 的良く対応することが判明した。(20)式には水面の初期形 状や衝撃圧力のピーク值に関する情報が含まれておらず, 注目に値する。

\section{5. 結言}

3 角形状の鉛直速度分布を有する平板まわりのポテンシ ヤル流れの解を利用した弾性影響を考慮しうる水面衝撃応 答解析手法を提案した。円筒壳の水面落下実験による動的 歪の計測結果と計算結果を比較したところ良好な対応が認 められた。次に平坦なクロスデッキパネルが放物線形状の 波頂に衝突する問題について動的応答シミュレーションを 行った結果, 次の点が明らかとなった。

1）パネルのスパン中央の最大撓みと曲げモーメントは 水面の曲率半径が大きくなるにつれ落下速度に比例する傾 向を示し, 比例定数は水面の曲率半径にも依存しなくなる 傾向を示す。

2）衝撃圧力のピーク值はパネルの動的応答には直接大 
きな影響を与えないと考えられる。また衝撃圧力を接水長 さで積分した衝撃力は落下速度の 2 乗に比例するが, これ を用いた準静的な応答は落下速度が大きい場合には実際の 動的応答に比べ過大になる可能性がある。

3）スパン中央最大撓みが落下速度に比例する理由は動 的応答倍率の低下によって説明できる。またエネルギ一的 考察から最大撓みが水面形状とは無関係に落下速度に比例 するという関係式を導くことができた。

\section{参 考 文 献}

1）渋江唯司, 伊東章雄, 中山英治：水面衝撃を受ける 円筒款の構造応答解析, 日本造船学会論文集, 第 174 号 (1993)

2）高木健: 水面衝撃問題における弾性の影響, 関西造 船協会誌, 第 222 号 (1994)

3) Kvålsvold, J., Faltinsen, O., M., Aarsnes, J., V.: Effect of Structural Elasticity on Slamming against Wetdecks of Multihull Vessels, Proc. 6th International Symposium on Practical Design of Ships and Mobile Units (PRADS' 95) (1995)

4) Kvålsvold, J., Faltinsen, O., M.: Hydroelastic
Modeling of Wet Deck Slamming on Multihull Vessels, Journal of Ship Research, Vol. 39, No. 3 (1995)

5) Kvålsvold, J., Faltinsen, O., M., Aarsnes, J., V.: Wave Impact on a Horizontal Elastic Plate, Journal of Marine Science and Technology, SNAJ (1997)

6）角洋一, 岡田真三, 向井広樹, 井上弘一：微小水撃角 における弾性平板の水面衝撃の研究, 日本造船学会 論文集, 第 182 号 (1997)

7）荒井誠, 宮内達哉：水面衝撃をうける円筒殻の流 体・構造連成応答シミュレーション, 日本造船学会 論文集, 第 182 号 (1997)

8) Wagner, V., H. : Über Stoß und Gleitvorgänge an der Oberfläche von Flüssigkeiten, Zeitschrift für Angewandte Mathematik und Mechanik, Band 12, Heft 4 (1932)

9）遠山泰美：任意形状物体の 2 次元水面衝撃計算法に ついて, 日本造船学会論文集, 第 173 号 (1993)

10）遠山泰美: 平板近似による 3 次元水面衝撃計算法に ついて, 日本造船学会論文集, 第 179 号（1996） 